\title{
Pola Pembinaan Terhadap Narapidana Seumur Hidup Dalam Kebijakan Implementasinya ${ }^{1}$
}

\author{
Nys. Arfa, Syofyan Nur, Yulia Monita ${ }^{2}$ \\ Fakultas Hukum, Universitas Jambi
}

\begin{abstract}
ABSTRAK
Pembinaan narapidana di Indonesia berdasarkan pada Undang-Undang Nomor 12 Tahun 1995 Tentang Pemasyarakatan. Pembinaan narapidanaa itu sendiri terdiri dari narapidana waktu tertentu tidak lebih dari 20 (dua puluh) tahun dan narapidana seumur hidup menjalani hukuman sampai meninggal dunia. Permasalahan yang muncul adalah terkait dengan pembinaan narapidana seumur hidup yang pembinaannya bersifat jangka panjang, karena tidak dapat diketahui pasti kapan seseorang meninggal. Sementara pembinaan narapidana berdasarkan paraturan perundang-undangan yang berlaku adalah pola pembinaan secara umum untuk seluruh narapidana taanpa membedakan lama pidana dari narapidanaa itu sendiri. Berdasarkan hal tersebut maka permasalahan yang akan diteliti adalah bagaimana pola pembinaan narapidana seumur hidup tersebut dalam kebijakan implementasinya. Metode yang dipergunakan dalam penelitian ini adalah metode penelitian hukum normatif dimana dalam penelitian ini nanti akan dikaji mengenai kebijakan hukum pidana dalam pembinaan narapidana seumur hidup, pendekatan penelitian yang digunakan adalah pendekatan undang-undang dan pendekatan konseptual, bahan hukum yang digunakan terdiri dari bahan hukum primer dan bahan hukum sekunder. Berdasarkan hasil penelitian yang telah dilakukan, bahwa pola pembinaan narapidana seumur hidup didasarkan pada peraturan perundang-undangan yang berlaku yaitu pola pembinaan yang berlaku secara umum untuk seluruh narapidana tanpa membedakan lama pidana yang yang dijatuhkan terhadap narapidana. Terhadap narapidana yang dijatuhi pidana seumur hidup belum ada peraturan perundang-undangan yang mengatur secara khusus terkait dengan pembinaannya. Dengan kata lain pembinaan narapidana seumur hidup mengikuti pada paraturan perundang-undangan yang sudah ada. Sistem pemasyarakatan memberikan pembinaan sesuai tahapan baku. Kebijakan implementatif tetap menempatkan narapidana seumur hidup berada di dalam sistem pemasyarakatan, akan tetapi agak sulit menentukan tahapan-tahapan pembinaannya karena masa pidana dari narapidana seumur hidup tidak terbatas.
\end{abstract}

Kata kunci: Pembinaan, Narapidana Seumur Hidup, Kebijakan, Implementasi

\section{PENDAHULUAN}

Masyarakat terdiri dari kumpulan individu maupun kelompok yang mempunyai latar belakang serta kepentingan yang berbeda-beda, sehingga dalam melakukan proses interaksi sering terjadi benturan kepentingan yang dapat menimbulkan konflik diantara pihak-pihak yang bertentangan tersebut. Dalam kehidupan bermasyarakat, tidak lepas dari kaidah hukum yang mengatur masyarakat itu. Kaidah hukum itu berlaku untuk seluruh masyarakat. Apabila dalam kehidupan mereka melanggar kaidah hukum itu, baik yang berupa kejahatan maupun pelanggaran, maka akan dikenakan sanksi yang disebut pidana.

Apa yang dewasa ini disebut sebagai Lembaga Pemasyarakatan adalah suatu lembaga, yang dahulu juga dikenal sebagai rumah penjara, yaitu tempat dimana orang-orang yang telah dijatuhi pidana dengan pidana-pidana tertentu oleh hakim itu harus menjalankan pidana mereka. ${ }^{3}$

Pada awalnya pembinaan narapidana di Indonesia menggunakan sistem kepenjaraan. Model pembinaan seperti ini sebenarnya sudah dijalankan jauh sebelum Indonesia merdeka. Dasar hukum atau undang-undang yang digunakan dalam sistem kepenjaraan adalah

\footnotetext{
${ }^{1}$ Berdasarkan hasil penelitian kelompok dana DIPA Fakultas Hukum Universitas Jambi Tahun 2019

${ }^{2}$ Dosen Fakultas Hukum Universitas Jambi

${ }^{3}$ Lamintang, Hukum Panitensier, Edisi Kedua, Sinar Grafika, Jakarta, 2012, hal. 165.
} 
Reglemen penjara, aturan ini telah digunakan sejak tahun $1917 .{ }^{4}$ Bisa dikatakan bahwa perlakuan terhadap narapidana pada waktu itu adalah seperti perlakuan penjajah Belanda terhadap pejuang yang tertawan. Mereka diperlakukan sebagai objek semata yang dihukum kemerdekaannya, tetapi tenaga mereka sering kali dipergunakan untuk kegiatan-kegiatan fisik. Ini menjadikan sistem kepenjaraan jauh dari nilai-nilai kemanusiaan dan hak asasi manusia.

Dengan demikian tujuan diadakannya penjara sebagi tempat menampung para pelaku tindak pidana dimaksudkan untuk menbuat jera (regred) dan tidak lagi melakukan tindak pidana. Untuk itu peraturan-peraturan dibuat keras, bahkan sering tidak manusiawi. ${ }^{5}$ Bertolak dari pandangan Sahardjo, tentang hukum sebagai pengayoman. Hal ini membuka jalan perlakuan terhadap narapidana dengan cara pemasyarakatan sebagai tujuan pidana penjara. ${ }^{6}$ Gagasan yang pertama kali muncul tentang perubahan tujuan pembinaan narapidana dari sisten kepenjaraan ke sistem pemasyarakatan adalah dikemukakan oleh Sahardjo. Menurut Sahardjo tujuan pemasyarakatan mempunyai arti:

Bahwa tidak saja masyarakat yang diayomi terhadap diulangi perbuatan jahat oleh terpidana, melainkan juga yang telah tersesat diayomi dengan memberikan kepadanya bekal hidup sebagai warga yang berguna dalam masyarakat. Dari pengayoman itu nyata bahwa menjatuhkan pidana bukanlah tindakan balas dendam dari negara... Tobat tidak dapat dicapai dengan penyiksaan, melainkan dengan bimbingan. Terpidana juga tidak dijatuhi pidana penyiksaan, melainkan pidana hilang kemerdekaan.... Negara mengambil kemerdekaan seseorang dan pada waktunya akan mengembalikan orang itu ke masyarakat lagi, mempunyai kewajiban terhadap orang terpidana itu dalam masyarakat. ${ }^{7}$

Konsepsi sistem baru pembinaan narapidana menghendaki adanya penggantian dalam undang-undang, menjadi undang-undang Pemasyarakatan. Undang-undang ini akan menghilangkan keseluruhan bau liberal-kolonial. ${ }^{8}$

Berdasarkan pemikiran tersebut, maka sejak tahun 1946 sistem pembinaan bagi narapidana dan anak pidana telah berubah secara mendasar, yaitu dari sistem kepenjaraan menjadi sistem pemasyarakatan. Begitu pula institusinya yang semula disebut Rumah Penjara dan Rumah Pendidikan Negara berubah menjadi Lembaga Pemasyarakatan berdasarkan Surat Instruksi Kepala Direktorat Pemasyarakatan Nomor J.H.G.8/506 Tanggal 17 Juni 1964. Lebih lanjut sistem pelaksanaan pidana penjara dengan sistem pemasyarakatan di Indonesia saat ini mengacu kepada Undang-Undang Nomor 12 Tahun 1995 tentang Pemasyarakatan.

Sistem pemasyarakatan merupakan suatu rangkaian kesatuan penegakan hukum pidana, oleh karena itu dalam pelaksanaannya narapidana bukan saja objek melainkan subjek yang tidak berbeda dengan manusia lainnya yang sewaktu-waktu dapat melakukan kesalahan atau kekhilafan yang dapat dikenakan pidana, sehingga tidak harus diberantas. ${ }^{9}$

Dalam hal melakukan pembinaan dan pembimbingan di Lembaga Pemasyarakatan, narapidana tidak dapat dibaurkan menjadi satu kesatuan. Lebih lanjut dalam Pasal 12 Undang-Undang Nomor 12 Tahun 1995 menyatakan bahwa:

Dalam rangka pembinaan narapidana di LAPAS dilakukan penggolongan atas dasar:

a. Umur;

b. Jenis kelamin;

\footnotetext{
${ }^{4}$ Harsono, Sistem Baru Pembinaan Narapidana, Djambatan, Jakarta, 1995, hal. 8

${ }^{5}$ Ibid., hal. 9-10. hal. 97.

${ }^{6}$ Dwidja Priyatno, Sistem Pelaksanaan Pidana Penjara Di Indonesia, Rafika Aditama, Jakarta, 2009,

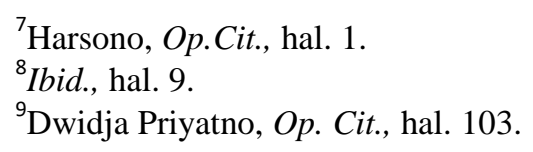


c. Lama pidana yang dijatuhkan;

d. Jenis kejahatan;

e. Kriteria lainnya sesuai dengan kebutuhan atau perkembangan pembinaan.

Dari uraian di atas, pada point huruf $\mathrm{c}$ dalam pembinaan narapidana digolongkan atas dasar lamanya pidana yang dijatuhkan. Lebih lanjut di dalam Kitab Undang-undang Hukum Pidana ketentuan umum tentang lama pidana yang dijatuhkan diatur pada Pasal 12 yang menyatakan:

(1) Pidana penjara ialah seumur hidup atau selama waktu tertentu.

(2) Pidana penjara selama waktu tertentu paling pendek satu hari dan paling lama lima belas tahun berturut-turut

(3) Pidana penjara selama waktu tertentu boleh dijatuhkan untuk dua puluh tahun berturut-turut dalam hal kejahatan yang pidananya hakim boleh memilih antara pidana mati atau, pidana seumur hidup, dan pidana penjara selama waktu tertentu; begitu juga dalam hal batas lima belas tahun dilampaui sebab tambahan pidana karena perbarengan (concursus), pengulangan (recidive) atau karena yang ditentukan dalam Pasal 52.

(4) Pidana penjara selama waktu tertentu sekali-kali tidak boleh melebihi dua puluh tahun.

Berdasarkan ketentuan Pasal 12 KUHP dapat disimpulkan ketentuan umum tentang lama pidana yang dijatuhkan adalah seumur hidup dan selama waktu tertentu sekali-kali tidak boleh melebihi dua puluh tahun. Berkaitan dengan hal tersebut di atas, terhadap terpidana yang telah dijatuhi hakim dengan hukuman penjara seumur hidup menjalani hukumannya di Lembaga Pemasyarakatan dalam rangka pembinaan digolongkan sebagai narapidana seumur hidup.

Persepsi masyarakat tentang narapidana seumur hidup relatif beragam, masyarakat dari berbagai kalangan yang mereka ketahui bahwa narapidana seumur hidup ini akan berada selamanya di LAPAS sampai dengan napi tersebut meninggal, ada juga yang menyatakan narapidana seumur hidup ini akan menjalani masa pidananya sesuai dengan umur mereka pada saat masuk LAPAS kemudian di komulatifkan.

Sehubunagn dengan hal tersebut, dilihat dari sudut penjatuhan pidana dan juga dari sudut terpidana, pidana seumur hidup itu bersifat pasti (definite sentence) karena siterpidana dikanakan jangka waktu yang pasti (a definite period of time), yaitu menjalani pidana sepanjang hidupnya, walaupun orang tidak tahu pasti berapa lama masa hidup seseorang di dunia. $^{10}$

Lebih lanjut merujuk kembali pada KUHP dari isi Pasal 12 ayat (1) tersebut, dapat disimpulkan bahwa yang dimaksud dengan pidana penjara seumur hidup adalah pidana penjara selama narapidana masih hidup hingga meninggal. Jadi, dari uraian di atas dapat dipahami dasar hukum mengapa pidana penjara seumur hidup berarti penjara sepanjang narapidana masih hidup, dan hukumannya baru akan berakhir setelah kematiannya.

Pembinaan narapidana di Lembaga Pemasyarakatan tidak terlepas dari tujuannya bahwa narapidana dibina dan dibimbing supaya menjadi lebih baik dan dapat diterima kembali di dalam masyarakat. Selanjutnya mengenai pola pembinaan narapidana di Lembaga Pemasyarakatan mengacu pada ketentuan yang terdapat di dalam Undang-Undang Nomor 12 Tahun 1995 Tentang Pemasyarakatan termasuk peraturan pelaksananya seperti Peraturan Pemerintah Republik Indonesia Nomor 31 Tahun 1999 Tentang Syarat dan Tata Cara pelaksanaan Hak Warga Binaan Pemasyarakatan, Peraturan Menteri Kehakiman Republik indonesia Nomor: M.01.10 Tahun 1989 Tentang Asimilasi, Pembebasan Bersyarat dan Cuti

\footnotetext{
${ }^{10}$ Barda Nawawi Arief, Bunga Rampai Kebijakan Hukum Pidana-Perkembangan Penyusunan Konsep KUHP baru, Kencana, Jakarta, 2014, hal. 225.
} 
menjelang Bebas, Keputusan Menteri Kehakiman Republik Indonesia Nomor: M.02PK.04.10 Tahun 1990 Tentang Pola Pembinaan Narapidana/Tahanan Menteri Kehakiman Republik indonesia.

Berdasarkan ketentuan yang diatur dalamUndang-Undang Pemasyarakatan dan peraturan pelaksanaannya tersebut dapat ditarik kesimpulan bahwa secara yuridis normatif atau menurut ketentuan peraturan perundang-undangan, pola pembinaan yang dilakukan oleh lembaga pemasyarakatan adalah pola pembinan yang berlaku secara umum untuk seluruh narapidana, tanpa membedakan lama pidana yang dijatuhkan apakah narapidana selama waktu tertentu atau narapidana seumur hidup. Dengan demikian, narapidana selama waktu tertentu sesuai dengan lama pidana yang dijatuhkan setelah berakhir masa hukumannya dapat kembali ke masyarakat, sedangkan narapidana seumur hidup dalam proses pembinaannya bersifat jangka panjang yang waktunya tidak dapat diketahui. Maka dapat dikatakan bahwa ketentuan mengenai pembinaan narapidana yang berlaku sekarang ini disamakan tanpa membedakan lama pidana yang dijatuhkan.

Pidana seumur hidup, bukanlah pidana sementara, karena batas waktunya belum jelas. Tetapi pidana itu dapat diubah menjadi pidana sementara. ${ }^{11}$ Hal ini dapat dilihat dalam ketentuan Pasal 7 Keputusan Presiden Republik Indonesia Nomor 5 Tahun 1987 dibuka kemungkinan bagi narapidana seumur hidup memperoleh remisi, dengan syarat pidana telah diubah dari pidana seumur hidup menjadi pidana penjara selama waktu tertentu. Pasal 7 ayat (2) Keputusan Presiden Republik Indonesia Nomor 5 Tahun 1987 menyatakan: "Perubahan pidana penjara seumur hidup menjadi pidana penjara sementara dilakukan oleh presiden". Dengan demikian, narapidana yang menjalani pidana penjara seumur hidup dapat berubah menjadi pidana penjara selama waktu tertentu melalui grasi.

Di Indonesi pidana penjara seumur hidup dapat diubah (dikomutasi) menjadi pidana penjara sementara waktu. Berdasarkan Pasal 9 Keputusan Presiden Republik Indonesia Nomor 174 Tahun 1999 Tentang Remisi, dinyatakan bahwa:

(1) Narapidana yang dikenakan pidana penjara seumur hidup dan telah menjalani pidana paling sedikit 5 (lima) tahun berturut serta berkelakuan baik, dapat diubah pidananya menjadi pidana penjara sementara, dengan lama sisa pidana yang masih harus dijalani paling lama 15 (lima Belas) tahun.

(2) Perubahan pidana penjara seumur hidup menjadi pidana sementara sebagaimana dimaksud dalam ayat (1) ditetapkan dengan Keputusan Presiden

(3) Permohonan perubahan pidana penjara seumur hidup menjadi pidana penjara sementara diajukan narapidana yang bersangkutan kepada Presiden melalui Menteri Hukum dan Perundang-Undangan (Saat ini Menteri Hukum dan HAM). ${ }^{12}$

Dalam hal peraturan baik itu undang-undang maupun peraturan lainnya yang berkenaan dengan pembinaan terhadap narapidana yang dijatuhi hukuman seumur hidup tersebut tidak terlihat adanya pengaturan yang memperlakukan secara khusus. Dengan kata lain pengaturan mengenai pola pembinaan narapidana seumur hidup disamakan dengan narapidana waktu tertentu, padahal pembinaannya bersifat jangka panjang, maka dalam penbinaannya perlu adanya kebijakan implementatif terhadap pembinaan narapidana seumur hidup tersebut.

Beranjak dari keadaan di atas maka penulis tertarik untuk melakukan kajian ilmiah tentang Pola Pembinaan Terhadap Narapidana Seumur Hidup Dalam Kebijakan Implementasinya agar nantinya diperoleh suatu gambaran tentang pola pembinaan narapidana seumur hidup. Untuk membatasi kajian penelitian, maka permasalahan dibatasi pada persoalan yang dianggap sangat mendasar, yaitu:bagaimana pola pembinaan terhadap narapidana seumur hidup dalam kebijakan implementasinya?

\footnotetext{
${ }^{11}$ Harsono, Op. Cit., hal. 26.

${ }^{12}$ Dwidja Prayitno, Op. Cit., hal. 73-74.
} 


\section{TINJAUAN PUSTAKA}

\subsection{Tinjauan Umum Pembinaan Narapidana}

Pembinaan yang ada pada Lembaga Pemasyarakatan pada dasarnya adalah mengenai arah pelayanan, pembinaan dan bimbingan yang perlu dilakukan oleh petugas ialah memperbaiki tingkah laku narapidana agar tujuan pembinaan dapat dicapai, oleh karena itu di dalam Keputusan Menteri Kehakiman Republik Indonesia Nomor: M.02-PK.04.10 Tahun 1990 Tentang Pola Pembinaan Narapidana/Tahanan, ruang lingkup pembinaan narapidana meliputi:

1. Pembinaan Kepribadian

Pembinaan kepribadian diarahkan pada pembinaan mental dan watak agar narapidana menjadi manusia seutuhnya, bertaqwa dan bertanggungjawab kepada diri sendiri, keluarga dan masyarakat.

Pembinaan Kepribadian terdiri dari:

a. Pembinaan kesadaran beragama

b. Pembinaan kesadaran berbangsa dan bernegara

c. Pembinaan kemampuan intelektual (kecerdasan)

d. Pembinaan kesadaran hukum

e. Pembinaan mengintegrasikan diri dengan masyarakat.

2. Pembinaan Kemandirian

Pembinaan kemandirian diarahkan pada pembinaan bakat dan keterampilan agar warga binaan dapat kembali berperan sebagai anggota masyarakat yang bebas dan bertanggungjawab, pembinaan kemandirian ini dapat diberikan melalui program-program antara lain:

a. Keterampilan untuk mendukung usaha mandiri; misalnya kerajinan tangan dan sebagainya.

b. Keterampilan untuk mendukung usaha-usaha industri kecil, misalnya pengelolaan bahan mentah dari sektor pertanian dan bahan alam menjadi bahan setengah jadi.

c. Keterampilan yang dikembangkan sesuai dengan bakatnya masing-masing, misalnya memiliki kemampuan di bidang seni, maka diusahakan untuk dapat mengembangkan bakatnya sekaligus mandapat nafkah.

d. Keterampilan untuk mendukung usaha-usaha industri atau kegiatan pertanian (perkebunan) dengan menggunakan teknologi madya atau teknologi tinggi, misalnya industri pembuatan sepatu kualitas ekspor, dan usaha tambak udang.

Bagi narapidana yang sisa pidananya lebih dari 1 (satu) tahun, menjalani dengan 4 (empat) tahap, yaitu:

a. Tahap pertama : Pembinaan awal yang didahului dengan masa pengamatan, penelitian, dan pengamatan lingkungan (mapenaling), sejak diterima sampi sekurang-kurangnya 1/3 (sepertiga) dari masa pidana yang sebenarnya.

b. Tahap kedua : Pembinaan lanjutan di atas 1/3 (sepertiga) sampai sekurang-kurangnya $1 / 2$ (seperdua) dari masa pidana yang sebenarnya.

c. Tahap ketiga : Pembinaan lanjutan di atas $1 / 2$ (seperdua) sampai sekurang-kurangnya 2/3 (dua pertiga) dari masa pidana yang sebenarnya.

d. Tahap keempat : Pembinaan lanjutan/bimbingan diatas 2/3 (dua pertiga) sampai dengan selesai pidana yang sebenarnya. 
Sedangkan bagi narapidana yang sisa pidananya sama dengan 1 (satu) tahun, ada tiga tahap, yaitu:

a. Tahap pertama, sejak diterima sampai sekurang-kurangnya $1 / 2$ dari masa pidana yang sebenarnya.

b. Tahap kedua, sejak $1 / 2$ sampai dengan sekurang-kurangnya $2 / 3$ masa pidana yang sebenarnya.

c. Tahap ketiga, sejak 2/3 sampai selesai masa pidananya.

Sedangkan proses bagi narapidana yang dipidana mati dan narapidana seumur hidup tidak dilakukan pentahapan, kecuali setelah dirubah pidananya menjadi pidana sementara.

Ketentuan di atas tidak jauh berbeda dengan ketentuan yang diatur dalam Peraturan Pemerintah Nomor 31 Tahun 1999 Tentang Pembinaan dan Pembimbingan Warga Binaan Pemasyarakatan yang diatur dalam Pasal 7, yang menentukan bahwa:

Tahap pembinaan narapidana dilakukan dengan beberapa tahap, yaitu:

1. Tahap awal, sebagaimana dimaksud dalam Pasal 9 ayat (1) pembinaan narapidana dimulai sejak yang bersangkutan berstatus sebagai narapidana sampai dengan 1/3 dari masa pidana.

Dalan Pasal 10, pada tahap awal dilakukan hal-hal:

a. Masa pengamatan, pengenalan diri dan penelitian lingkungan paling lama 1 (satu) tahun

b. Perencanaan program pembinaan kemandirian dan kepribadian

c. Penilaian pelaksanaan program pembinaan awal.

2. Tahap lanjutan, sebagaimana dimaksud dalam Pasal 9 ayat (2) huruf a, tahap lanjutan pertama sejak berakhir pembinaan tahap awal sampai dengan $1 / 2$ dari masa pidana. Dan huruf $b$, tahap lanjutan kedua, sejak berakhir masa pembinaan tahap lanjutan pertama sampai dengan $2 / 3$ masa pidana.

3. Tahap akhir, sebagaimana dimaksud dalam Pasal 9 ayat (3) sejak berakhirnya tahap lanjutan sampai dengan berakhirnya masa pidana dari narapidana yang bersangkutan.

\section{METODE PENELITIAN}

Penelitian ini merupakan penelitian hukum yuridis normatif, sifat normatif penelitian hukum dikaitkan dengan karakter keilmuan itu sendiri. Karena itu pemilihan metode penelitian senantiasa dibatasi oleh rumusan masalah, objek yang diteliti dan tradisi keilmuan hukum itu sendiri.

Pendekatan penelitian yang digunakan dalam penelitian ini adalah pendekatan perundang-undangan (statute approach) dilakukan dengan cara menelaah semua undangundang yang saling berkaitan dengan isu hukum yang diteliti, dan pendekatan konseptual (conceptual approach) dilakukan dengan cara menelaah pandangan-pandangan dari doktrindoktrin yang berkembang di dalam ilmu hukum.

Dalam penelitian ini bahan-bahan hukum yang digunakan antara lain:

a. Bahan hukum primer

Bahan hukum primer adalah bahan-bahan hukum yang dijadikan dasar dalam menyusun penulisan penelitian yang diambil dari kepustakaan, diantaranya yaitu Undang-Undang Nomor 12 Tahun 1995 tentang Pemasyarakatan, Peraturan Pemerintah Nomor 31 Tahun 1999 Tentang Pembinaan dan Pembimbingan Warga Binaan Pemasyarakatan, Peraturan Pemerintah Nomor 32 Tahun 1999 Tentang Syarat dan Tata Cara Pellaksanaan Hak Warga Binaan Pemasyarakatan, Peraturan Menteri Hukum dan HAM Nomor: M.01.PK.04-10 tahun 2007 Tentang Syarat dan Tata Cara Pelaksanaan Asimilasi, Pembebasan Bersyarat, Cuti Menjelang Bebas dan Cuti Bersyarat, Keputusan Menteri Kehakiman Republik Indonesia Nomor: M.02-PK.04.10 Tahun 1990 Tentang Pola Pembinaan Narapidana/Tahanan Menteri Kehakiman Republik Indonesia 
b. Bahan hukum sekunder

Bahan hukum sekunder adalah bahan yang memberikan penjelasan mengenai bahan hukum primer, diantaranya yaitu diperoleh dengan mempelajari buku-buku, majalah, hasil penelitian, laporan kerja dan lain-lain yang berkaitan dengan penelitian ini.

Analisis bahan hukum dilakukan dengan cara:

1. Menginterpretasikan semua peraturan perundang-undangan sesuai masalah yang dibahas.

2. Menilai bahan-bahan yang berhubungan dengan masalah yang akan diteliti.

3. Mengevaluasi perundang-undangan yang berhubungan dengan masalah yang dibahas.

\section{POLA PEMBINAAN NARAPIDANA SEUMUR HIDUP DALAM KEBIJAKAN IMPLEMENTASINYA}

Pembinaan pada dasarnya merupakan suatu aktivitas atau kegiatan yang dilakukan secara sadar, berencana, terarah, dan teratur secara bertanggungjawab dalam rangka menumbuhkan, meningkatkan, dan mengembangkan kemampuan serta sumber-sumber yang tersedia untuk mencapai tujuan. Dalam hal ini, pembinaan yang dilakukan dilembaga pemasyarakatan adalah pembinaan terhadap narapidana, baik narapidana yang dijatuhi pidana waktu tertentu maupun narapidana yang dijatuhi pidana seumur hidup.

Berdasarkan data sebagaimana dikemukakan dalam bab terdahulu terlihat, bahwa peluang pidana seumur hidup untuk dijatuhkan sebagai jenis sanksi pidana dalam sistem hukum pidana di Indonesia cukup besar. Dalam hukum pidana di Indonesia masih banyak kelompok tindak pidana yang diancam dengan pidana seumur hidup baik tindak pidana yang diatur yang diatur dalam KUHP maupun tindak pidana yang diatur di luar KUHP.

Mengenai pembinaan naraapidana seumur hidup yang ada saat ini ataupun yang berlaku saat ini di Indonesia secara yuridis normatif berlandaskan pada Undang-Undang Nomor 12 Tahun 1995 tentang Pemasyarakatan, Peraturan Pemerintah Republik Indonesia Nomor 31 Tahun 1999 tentang Pembinaan dan Pembimbingan Warga Binaan Pemasyarakatan, Peraturan Pemerintah Nomor 32 Tahun 1999 Tentang Syarat dan Tata Cara Pembinaan dan Pembimbingan Warga Binaan, serta berdasarkan pada Keputusan Menteri Kehakiman Nomor: M. 02-PK.04.10 Tahun 1990 tentang Pola Pmbinaan Narapidana/Tahanan, yaitu dengan kata lain masalah pengaturan pembinaan narapidana seumur hidup di Indonesia disamakan dengan narapidana waktu tertentu lainnya.

Meita Eriza selaku Kasi Binadik Lapas Kelas II A Kota Jambi menjelaskan:.

Mengenai pembinaan terhadap narapida seumur hidup tidak ada aturan khusus dari lapas kelas II A Kota Jambi dalam hal pengaturan pembinaan terhadap narapidana seumur hidup. Setiap narapidana baik itu narapidana seumur hidup maupun narapidana lainnya, pembinaannya sama tanpa pengecualian, tidak pernah membedakan, tidak ada perlakuan khusus terhadap narapidana seumur hidup dalam pembinaannya. Pembinaan yang dilaksanakan berdasarkan pada peraturan perundang-undangan yang berlaku. ${ }^{13}$

Berdasarkan ketentuan Pasal 6 Undang-Undang Nomor 12 Tahun 1995, dinyatakan bahwa: "Pembinaan warga binaan pemasyarakatan dilakukan di lapas dan pembimbingan warga binaan pemasyarakatan dilakukan oleh Bapas. Sedangkan pembinaan dilapas dilakukan terhadap narapidana dan anak didik pemasyarakatan."

Selanjutnya Pasal 4 ayat (2), menyebutkan: "Dalam melaksanakan pembinaan sebagaimana yang dimaksud dalam ayat (1) Kepala Lapas menetapkan petugas pemasyarakatan yang bertugas sebagai Wali Narapidana."

Terhadap proses pembinaan di dalam lapas, bahwa setiap warga binaan termasuk juga narapidana seumur hidup didampingi seorang wali pemasyarakatan. Wali adalah petugas

\footnotetext{
${ }^{13}$ Wawancara dengan Meita Eriza, Kasi Binadik Lembaga Pemasyarakatan Kelas II A Kota Jambi.
} 
pemasyarakatan yang melakukan pendampingan narapidana menjalani program pembinaan di pemasyarakatan.

Berdasarkan hasil wawancara dengan Meita Eriza, menyatakan: "Setiap narapidana didampingi oleh wali, tanpa terkecuali untuk naparapidana seumur hidup, satu orang wali narapidana di lapas kelas II A kota Jambi mendampingi sekitar 20 sampai 30 orang narapidana." 14

Berdasarkan hasil wawancara dengan Kasi Binadik Lapas Kelas II A Kota Jambi Meita Eriza menjelaskan:

Pembinaan yang diberikan terhadap narapidana seumur hidup di Lapas Kelas II A Kota Jambi berupa pembinaan kepribadian dan pembinaan kemandirian. Pihak Lapas tidak pernah memisahkan kondisinya, bagaimanapun juga narapidana seumur hidup tersebut adalah warga binaan pemasyarakatan. Walaupun mendapat pidana seumur hidup, narapidana seumur hidup tersebut tetap dalam pembinaan, sama seperti apapun yang dilakukan oleh narapidana lain sebatas narapidana seumur hidup mau dan mampu melaksanakan pembinaan tersebut, mereka diikutkan. ${ }^{15}$

Pasal 7 ayat (1) Peraturan Pemerintah Republik indonesia Nomor 31 Tahun 1999 tentang Pembinaan dan Pembimbingan Warga Binaan Pemasyarakatan, pembinaan narapidana dilaksanakan melalui beberapa tahapan pembinaan, dan dalam Pasal 7 ayat (2) Peraturan Pemerintah Republik indonesia Nomor 31 Tahun 1999 tentang Pembinaan dan Pembimbingan Warga Binaan Pemasyarakatan, tahapan pembinaan yang sebagaimana dimaksud tersebut meliputi:

a. Tahap awal;

b. Tahap lanjutan; dan

c. Tahap akhir.

Berdasarkan Pasal 9 ayat (1) Peraturan Pemerintah Republik indonesia Nomor 31 Tahun 1999, pembinaan tahapa awal dimulai sejak yang bersangkutan berstatus narapidana sampai dengan 1/3 dari masa pidana. Pembinaan tahap awal meliputi:

a. Masa pengamatan, pengenalan dan penelitian lingkungan selama 1 (satu) bulan;

b. Perencanaan program pembinaan kepribadian dan kemandirian;

c. Pelaksanaan program pembinaan kepribadian dan kemandirian;

d. Penilaian pelaksanaan program pembinaan awal.

Pembinaan tahap akhir dilaksanakan sejak berakhirnya pembinaan tahap lanjutan sampai dengan berakhirnya masa pidana dari narapidana yang bersangkutan. Dalam Pasal 10 ayat (3) Peraturan Pemerintah Republik indonesia Nomor 31 Tahun 1999, pembinaan tahap akhir meliputi:

a. Perencanaan program integrasi;

b. Pelaksanaan program integrasi;

c. Pengakhiran pelaksanaan pembinaan tahap akhir.

Berdasarkan hasil wawancara dengan Meita Eriza selaku Kasi Binadik Lapas Kelas II A Kota Jambi menjelaskan:

Narapidana seumur hidup tidak masuk dalam pentahapan pembinaan. Artinya mereka belum pernah diikutkan ke dalam sidang Tim Pengamat Pemasyarakatan, maksudnya mereka tidak mendapat program pembinaan lanjutan, disebabkan narapidana seumur hidup tersebut tidak dapat diukur masa pidananya. Memang benar mereka tetap mendapatkan pembinaan, tapi tidak bisa beranjak ke pembinaan tahapan selanjutnya. Pembinaan mereka tidak dibatasi, sekali lagi dikatakan asal mereka mau dan mampu, mereka diikutkan. Apabila mereka berkelakuan baik selama pembinaan, narapidana seumur hidup tersebut berhak mengajukan

\footnotetext{
${ }^{14}$ Wawancara dengan Meita Eriza, Kasi Banadik Lembaga Pemasyarakatan Kelas II A Kota Jambi

${ }^{15}$ Wawancara dengan Meita Eriza, Kasi Binadik Lembaga Pemasyarakatan Kelas II A Kota Jambi.
} 
pengampunan kepada Presiden sesuai dengan ketentuan yang ada berlaku dan pihak lapas pasti mengupayakan usaha maksimal dan itu sudah pernah dilakukan. ${ }^{16}$

Bertolak pada hal tersebut di atas, nampaknya narapidana seumur hidup tidak dapat menjalankan proses pemasyarakatan sebagaimana telah ditetapkan, maksudnya narapidana seumur hidup dalam pembinaannya tidak dibatasi. Dengan demikian kebijakan implementasi dalam pembinaan narapidana seumur hidup tetap mengikuti ketetapan yang ada sampai narapidana seumur hidup mendapat perubahan masa pidana menjadi pidana sementara waktu. Perubahan narapidana seumur hidup menjadi narapidana sementara waktu berdasarkan Pasal 9 ayat (1) Keputusan Presiden Republik Indonesia Nomor 174 Tahun 1999 Tentang Remisi menyatakan bahwa: "Narapidana yang dikenakan pidana penjara seumur hidup dan telah menjalani pidana paling sedikit 5 (lima) tahun berturut serta berkelakuan baik, dapat diubah pidananya menjadi pidana penjara penjara sementara, dengan lama sisa pidana yang masih harus dijalani paling lama 15 (lima belas) tahun."

Berdasarkan hasil wawancara dengan Meita Eriza menjelaskan: "Mengenai program pembinaan, untuk narapidana seumur hidup tidak ada batasan dalam rangka pembinaan, akan tetapi memang dipilihkan waktu dan kegiatan yang sesuai dengan mereka serta tetap memperhatikan faktor keamanan."17

Dalam melakukan pembinaan terhadap narapidana dibutuhkan suatu metode pembinaan. Metode pembinaan merupakan cara dalam penyampaian materi pembinaan, agar secara efektif dan efisien dapat diterima oleh narapidana dan dapat memberikan perubahan dalam diri narapidana, baik itu perubahan dalam pola pikir, tingkah laku maupun dalam tindakan. Penyampaian materi tidak saja berdasar pada kesiapan si pemberi materi saja, tetapi juga harus diperhatikan kesiapan dari narapidana sendiri dalam menerimanya.

Berdasarkan hasil wawancara dengan Meita Eriza selaku Kasi Binadik Lapas Kelas II A Kota Jambi menjelaskan:

Untuk metode pembinaan, pihak lapas telah menetukan bentuk pembinaan yang akan diberikan terhadap seluruh warga binaan pemasyarakatan tanpa terkecuali untuk narapidana seumur hidup. Tidak ada perlakuan khusus terhadap mereka. Di samping itu, mengingat jumlah petugas, fasilitas yang ada belum memadai serta ditambah dengan jumlah warga binaan yang sudah over kapasitas, pihak lapas memberdayakan petugas dan fasilitas yang ada seefektif mungkin, sehingga hasil secara maksimal dapat diperoleh.

Dalam proses pembinaan narapidana, narapidana seumur hidup sangat apriori terhadap program atau pembinaan yang diberikan oleh lembaga pemasyarakatan. Hal ini karena mereka merasa pembinaan yang dilakukan tidak akan membawa manfaat terhadap dirinya karena kecilnya kemungkinan untuk keluar dari lembaga pemasyarakatan.

Berdasarkan uraian di atas, jika dilihat dari ide pemasyarakatan pada hakekatnya pidana perampasan kemerdekaan seseorang hanya bersifat sementara (untuk waktu tertentu) tidak untuk seumur hidup (untuk waktu yang tidak ditentukan). Dalam hal ini terjadi kontradiksi antara tujuan pidana seumur hidup dengan tujuan sistem pemasyarakatan. Sistem pemasyarakatan cenderung memberikan perlindungan individu yang tidak dapat dilaksanakan terhadap narapidana seumur hidup dengan alasan pembinaan narapidana seumur hidup dilaksanakan di dalam lembaga pemasyarakatan dengan tanpa batas waktu yang pasti. Selain itu penjatuhan pidana seumur hidup cenderung memberikan perlindungan masyarakat. Dalam pengamatan peneliti, narapidana seumur hidup yang telah menjalani masa pidana lebih dari 5 tahun dan berkelakuan baik, dapat mengajukan remisi menjadi pidana waktu tertentu, akan tetapi pengajuan remisis tersebut diajukan berulang-ulang belum disetujui, padahal narapidana seumur hidup yang bersangkutan telah layak untuk diberikan remisi.

\footnotetext{
${ }^{16}$ Wawancara dengan Meita Eriza, Kasi Binadik Lembaga Pemasyarakatan Kelas II A Kota Jambi

${ }^{17}$ Wawancara dengan Meita Eriza, Kasi Binadik Lembaga Pemasyarakatan Kelas II A Kota Jambi
} 
Kebijakan implementatif yang ada selama ini masih tetap menempatkan narapidana seumur hidup berada di dalam sistem pemasyarakatan, hanya saja sulit menetukan tahaptahap pembinaannya, oleh karena masa pidana tidak terbatas. Sistem pemasyarakatan memberikan kesempatan kepada narapidana seumur hidup untuk merubah masa pidananya menjadi pidana penjara waktu tertentu dngan syarat berkelakuan baik selama lebih dari 5 tahun dan hal tersebut telah diatur dalam peraturan perundang-undangan.

Berdasarakan uraian di atas, pola pembinaan terhadap narapidana seumur hidup dalam kebijakan implementasinya cenderung berusaha untuk menyesuaikan dengan sistem pemasyarakatan yang berorientasi pembinaan. Hal demikian ditempuh untuk mengatasi benturan kepentingan dalam konsep pemasyarakatan yang berorientasi kepada rehabilitasi dan resosialisasi narapidana untuk kembali ke masyarakat dan kepentingan untuk memisahkan narapidana dengan masyarakat dalam jangka waktu lama. Meskipun pemidanaan disahkan sebagai konsekuensi atas suatu perbuatan yang melanggar hukum, namun secara substansial dan pelaksanaannya hendaknya menghormati narapidana sebagai manusia yang dijadikan objek pemidanaan.

\section{KESIMPULAN DAN SARAN}

Pola pembinaan narapidana seumur hidup dalam kebijakan implementasinya, yakni belum ada peraturan perundang-undangan mengatur secara khusus terkait dengan pembinaan narapidana seumur hidup. Kebijakan implementasi dalam pembinaan narapidana seumur hidup mengikuti pada peraturan perundang-undangan yang sudah ada. Sistem pemasrakatan memberikan pembinaan sesuai tahapan baku. Kebijakan implementatif tetap menempatkan narapidana seumur hidup berada di dalam sistem pemasyarakatan, hanya saja sedikit sulit menetukan tahapan-tahapan pembinaannya, oleh karena masa pidana yang tidak terbatas.

Dalam pembinaan narapidana seumur hidup bersifat jangka panjang, maka hendaknya dilakukan pembinaan secara khusus dan terpusat yang intensif di lembaga pemasyarakatan dengan tingkat keamanan maximum security sehingga proses pembinaannya berjalan lebih baik dan efektif. Serta adanya bentuk yag jelas dalam pola pembinaan narapidana seumur hidup, peneliti mengusulkan untuk menetapkan pembinaan secara khusus mengenai pola pembinaan narapidana seumur hidup yang dituangkan bisa dalam bentuk kebijakan sehingga pembinaannya dapat terimplementasi dengan baik dan berdaya guna.

\section{DAFTAR PUSTAKA}

\section{BUKU}

Barda Nawawi Arief, 2014, Bunga Rampai Kebijakan Hukum Pidana-Perkembangan Penyusunan Konsep KUHP baru, Kencana, Jakarta.

Dwidja Priyatno, 2009,Sistem Pelaksanaan Pidana Penjara Di Indonesia, Rafika Aditama, Jakarta.

Harsono, 1995, Sistem Baru Pembinaan Narapidana, Djambatan, Jakarta.

Lamintang, 2012, Hukum Panitensier, Edisi Kedua, Sinar Grafika, Jakarta.

Peter Mahmud Marzuki, 2013, Penelitian Hukum, Edisi Kedua, Sinar Grafika, Jakarta

Rena Yulia, 2012, Viktimologi Perlindungan Hukum Terhadap Korban Kejahatan Cet. Pertama, Graha Ilmu, Yogyakarta.

Soenarko, 2003, Publik Policy, Airlangga University, Surabaya.

Suran Arbu Zanti, 2009, Rancangan Penelitian Kebijakan Sosial, Pustekom Dikbud dan CV. Rajawali, Jakarta. 
Tongat, 2004, Pidana Sumur hidup Dalam Sistem Hukum Pidana Di Indonesia, UMM Press, Malang.

Tangkilisan, 2003, Implementasi Kebijakan Publik, Lukman Offset, Jakarta.

Usman Nurdin, 2002, Kebijakan Implemntasi Publik, CV. Cipta Adi Karya, Bandung.

Widodo, 2014, Hukum Pidana Dan Penologi, Aswaja, Jogyakarta.

\section{Peraturan Perundang-Undangan}

Republik Indonesia, Menteri Kehakiman, Keputusan Menteri Kehakiman Tentang Pola Pembinaan Narapidana/Tahanan, Kepmen Kehakiman Nomor M.02-PK.04.10 Tahun 1990.

Republik Indonesia, Undang-Undang Tentang Pemasyarakatan, Undang-Undang Nomor 12 Tahun 1995, LNRI Tahun 1995 Nomor 77, TLNRI Nomor 3641.

Republik Indonesia, Peraturan Pemerintah Republik Indonesia Tentang Pembinaan Dan Pembimbingan Warga Binaan Pemasyarakatan. PP Nomor 31 Tahun 1999, LNRI Tahun 1999 Nomor 68, TLNRI Nomor 3845.

Republik Indonesia, Peraturan Pemerintah Republik Indonesia Tentang Syarat Dan Tata Cara Pelaksanaan Hak Warga Binaan Pemasyarakatan, PP Nomor 31 Tahun 1999, LNRI Nomor 69, TLNRI Nomor 3846. 